\title{
FLASH-FLOODS INFLUENCE MACROINVERTEBRATE COMMUNITIES DISTRIBUTION IN LOTIC ECOSYSTEMS
}

Octavian PACIOGLU*, Alina SATMARI **, Milca PETROVICI *, Mălina PÎRVU*, Mirela CÎMPEAN ***, Karina Paula BATTES ***, Sandra Florina LELE *, Angela CURTEAN-BĂNADDUC **** and Lucian PÂRVULESCU *C.A.

* West University of Timişoara, Faculty of Chemistry, Biology, Geography, Pestalozzi Street 16A, Timişoara, Romania, RO-300115, octavian.pacioglu@e-uvt.ro, milca.petrovici@e-uvt.ro, malina.pirvu@e-uvt.ro, sandra.lele@e-uvt.ro, lucian.parvulescu@e-uvt.ro (corresponding author)

** West University of Timişoara, Faculty of Chemistry, Biology, Geography, Department of Geography, Pârvan Boulevard 4, Timişoara, Romania, RO-300223, alina.satmari@e-uvt.ro

*** Babeș-Bolyai University, Faculty of Biology and Geology, Republicii Street 44, Cluj-Napoca, Romania, RO-400006, mirela.cimpean@ubbcluj.ro,karina.battes@ubbcluj.ro

**** "Lucian Blaga" University of Sibiu, Faculty of Sciences, Applied Ecology Research Center, Dr. Ion Raţiu Street 5-7, RO-550012 Sibiu, Romania, angela.banaduc@ulbsibiu.ro, ad.banaduc@yahoo.com

DOI: 10.2478/trser-2019-0004

KEYWORDS: catchment slope, ecological indicators, flash flood potential, habitat fragmentation, populations ecology.

\section{ABSTRACT}

Stream dwelling invertebrate populations are facing an ample array of stressors including the habitat imbalance caused by important floods. In this research we used a novel way to estimate the impact of floods upon the substrate, by utilising a remote variable named "flash-flood potential" (FFP), which accounts for the site slope and the average slope of the upstream catchment. The results showed that certain groups are sensitive to the influence of the FFP whereas other are not. We propose this remote variable as a surrogate for assessing stress imposed by floods and sediment scouring for lotic macroinvertebrates.

RÉSUMÉ: Influencia de inundaciones repentinas en la distribución de comunidades de macroinvertebrados en ecosistemas lóticos.

Las poblaciones de macroinvertebrados fluviales enfrentan una gran variedad de amenazas, que incluyen la inestabilidad del hábitat a causa de fuertes inundaciones. En este estudio se utilizó un enfoque novedoso para estimar el impacto de las inundaciones en el sustrato, que consiste en el uso de una variable remota llamada "potencial de inundación rápida" (FFP), la cual da cuenta de la pendiente del sitio y la pendiente promedio de la cuenca de captación. Los resultados mostraron que ciertos grupos son sensibles a la influencia del FFP, y otros no. Se propone el FFP como variable sinóptica para evaluar el estrés impuesto en las poblaciones de invertebrados lóticos por parte de las inundaciones y la erosión de sedimentos.

REZUMAT: Viiturile influențează distribuția cumunităților de macronevertebrate în ecosistemele lotice.

Populațiile macronevertebratelor lotice sunt supuse unei palete foarte largi de factori de stres, inclusiv instabilitatea substratului cauzată de inundații severe. În acest studiu a fost utilizată o abordare nouă pentru estimarea impactului inundațiilor asupra substratului, prin folosirea unei variabile numite "potențialul de inundație" (FFP), care ia în calcul panta râului dar și a pantei medii a bazinului hidrografic situat în amonte de stația de prelevare. Rezultatele au arătat faptul că anumite grupe taxonomice sunt sensibile la influenta acestei variabile în timp ce alte grupe nu au fost afectate. Propunem folosirea acestei variabile ca un surogat pentru evaluarea stresului indus de inundații asupra macrozoobentosului lotic. 


\section{INTRODUCTION}

Natural and/or anthropogenic significant events influence continuously the aquatic biota presence or absence, distribution and zoogeography, and ecological status (Resh et al., 1988; Bailey et al., 1998; Staicu et al., 1998; Lake et al., 2000; Anastasiu et al., 2017; Marić et al., 2017).

Infrequent, severe flood events have a direct negative impact upon most freshwater invertebrates, especially when associated with debris flow (Palmer et al., 1996; Relyea et al., 2012) and lack of suitable shelters and refuges (Culp and Davies, 1983; Townsend and Hildrew, 1994). However, floods induce different responses in different taxa. The larvae of freshwater insects are usually more affected compared to other type of invertebrates, although communities can be re-established afterwards through aerial colonisations (Tronstad et al., 2007). On the other hand, invertebrates with a complete aquatic life cycle (non-insects) need a longer period to re-colonise streams after major flood events (Wallace, 1990).

Besides dislodging invertebrates from substrate, another major stress imposed by high flows is the quantity of fine sediments carried downstream (Jones et al., 2012). Following the aftermath of mid-high-power floods, the invertebrate communities are hampered by space availability in both benthic and hyporheic habitats (Dole-Olivier, 2011). As such, different types of macroinvertebrates prefer various types of substrates: oligochaetes (Armitage, 1995) and chironomids (Dudgeon, 1994) are generally associated with fine sediment deposition, whereas other groups of invertebrates cannot withstand intrusion of small particles because of the detrimental effect on dissolved oxygen intake and hence, respiration (Eriksen, 1966; Lemly, 1982). At the other end of the spectrum, erosional, coarser deposits are usually inhabited by a higher frequency of mayfly, stonefly and caddisfly larvae due to a higher availability of dissolved oxygen in substrate (Nebeker, 1972; Wiley and Kohler, 1980; Williams et al., 1987), whereas amphipods and ceratopogonids tend to inhabit fissured and depositional zones (Pennak, 1989; Merritt and Cummins, 1996; Weigel et al., 2003; Kley et al., 2009).

To overcome the knowledge gap induced by the combination of several detrimental events associated with floods, a new variable, named "flash-flood potential" (FFP) was proposed to estimate the impact of irregular high flows upon substrate availability and hence of the invertebrate community stability in streams (Pârvulescu et al., 2016). The FFP accounts for the site slope and the average slope of upstream basins and proved to be a good indicator for assessing the spatial distribution of different size-classes of crayfish in rivers (Pârvulescu et al., 2016). This study goal was to test how this variable predicts the occurrence of various groups of macroinvertebrates inhabiting lotic systems covering a wide variety of catchments slopes within Romania. The taxonomic resolution used was undertaken at a very coarse level (order, class or higher) for two reasons. First, previous studies investigating the effects of floods and substrate availability in shaping invertebrate community structure in streams recognised that major differences within various groups of aquatic invertebrates take place at coarse taxonomic levels (e.g. usually order for insects or even higher for other groups like oligochaetes and nematodes), and that lower taxonomic resolution requires supplementary efforts that does not always bring any significant improvements to the observed patterns (Warwick, 1988; Bowman and Bailey, 1997). Second, such an approach would allow ecologists and local stakeholders, less trained in taxonomy, to assess the impact of detrimental abiotic events on river ecosystems, like floods and sediment scouring potential (Statzner and Beche, 2010). Identification to lower taxonomic levels can be time consuming and therefore expensive and often does not clarify community responses to stressors (Bonada et al., 2006). 


\section{MATERIAL AND METHODS}

The dataset employed in this study was obtained by field investigation of 408 rivers sites selected in Romania during the summer season (July-August) between 2009 and 2015 (Fig. 1).

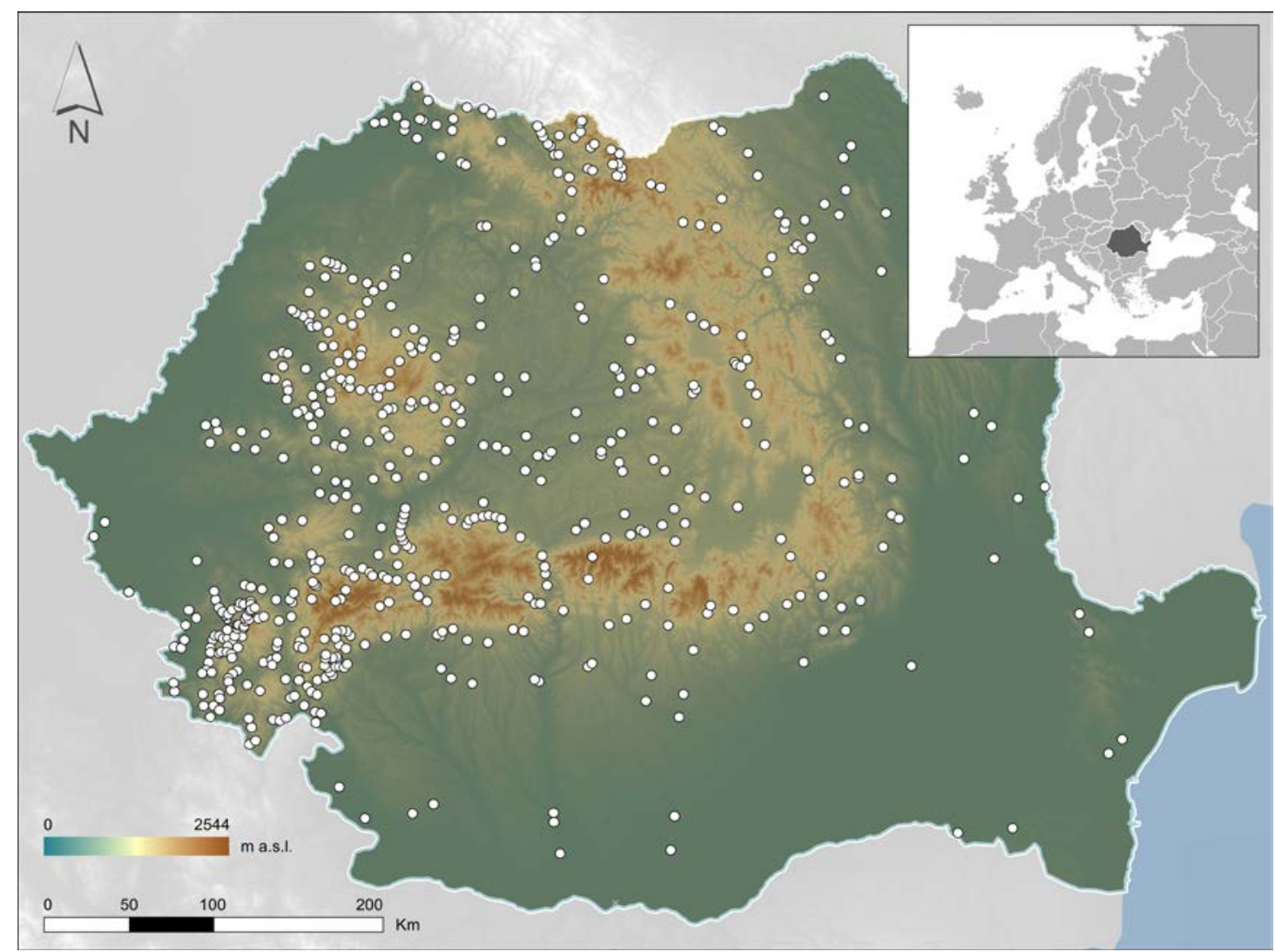

Figure 1: Map showing the sampling points within hydrographical basins in Romania.

The geographical position of each site was recorded with a Garmin GPS receiver (Garmin Ltd., Lenexa, Kansas, United States).

The invertebrates were sampled by employing kick net sampling standard protocol using a standard one mm mesh pond (hand) net (Storey et al., 1991).

Following sampling, the content was transferred in sealed plastic recipients, preserved with $4 \%$ formalin solution and further identified in the laboratory to coarse taxonomic resolution (order or higher). 
FFP was calculated as the product of two land-surface variables, namely slope gradient (G) and catchment slope (CS). Both variables were derived from a $90 \mathrm{~m}$ SRTM DEM (http://srtm.csi.cgiar.org). G was computed in a standard 3 X 3 neighbourhood. This variable estimates local declivity, thus accounting for the potential water velocity at a given site. CS was computed as follows: for each cell, $G$ was calculated and then accumulated downslope (for the entire area that drains towards a cell, not only for the river beds itself). Then, the value of accumulated slope for each cell was divided by the catchment area of that cell (http://www.saga-gis.org/en/index.html). CS estimates the average gradient of a surface that drains towards a given site, thus accounting for the potential of flash-floods and their associated disturbing effects as a consequence of heavy rain falls. Therefore, FFP estimates, the potential for disturbance in streams, by taking into account the potential drainage velocity both upstream and at the site. For further details, we refer readers to Pârvulescu et al. (2016).

\section{Statistical analysis}

The values employed in statistical analyses were the relative frequencies of each taxonomic group and logarithmic values of FFP. It was considered a limiting response model (Lancaster and Belyea, 2006), using log-linear regression to describe the rate of change with respect to FFP near the upper boundary of the conditional distribution of invertebrate's frequencies. Therefore, we focused on modelling the distribution of the response at the 90th percentile $(\tau=0 \bullet 9)$. Each taxonomic group was tested using quantile regression, followed by the goodness of fit with the observed pattern with the aid of the Wald test (Tab. 1). We have focused on log-linear models because of monotonic response expected for invertebrates to FFP variation (Pârvulescu et al., 2016). All tests were undertaken in XLSTAT version 2010 package.

Classification and regression trees ( $\mathrm{C}$ and $\mathrm{RT}$ ) were employed in this study, aiming for the identification of potential response and to predict an optimum value of frequency occurrence of different groups of invertebrates for different classes of FFP. Despite the difficulty in the interpretation of large trees, there are obvious advantages provided by different responses: the invariance to transformation of variables, simplicity of models and ease in managing missing values (De'ath and Fabricius, 2007). In our case, the predictive variable was the FFP (Tab. 2). Other advantages of this method are the simple graphical representation which is an upside down branching tree with nodes based on the value of one or more explanatory variables (Moldovan et al., 2013). The parent node is split into child nodes and they become, in turn, parent nodes unless they are terminal nodes (De'ath, 2002). In this study, C and RT's were used to build predictive models for the presence and optimum frequencies of invertebrates at different classes of FFP. The Chi-squared Automatic Interaction Detector (CHAID) technique (Kass, 1980) was used to construct trees where each node represents a split that yields optimum prediction for the targeted invertebrate species (Tab. 2). This way, the optimal frequencies for several classes of FFP are estimated for each taxonomic group (De'ath, 2002). Therefore, CHAID builds trees with more than two branches attached to a single node, based on an algorithm which in turn is based on chi-square tests. The decision trees were developed within XLSTAT Version 2010 package and interpreted at 5\% significance level. For more detailed information about the usefulness and criteria of this method see Pacioglu et al. (2016). 


\section{RESULTS}

The FFP values used in this survey varied widely (between 0-8, Fig. 2), covering a large range of river morphologies and topographic slopes, ranging from steep mountain valleys to lowland rivers with very small slopes, and hence reduced FFP values (Fig. 1).
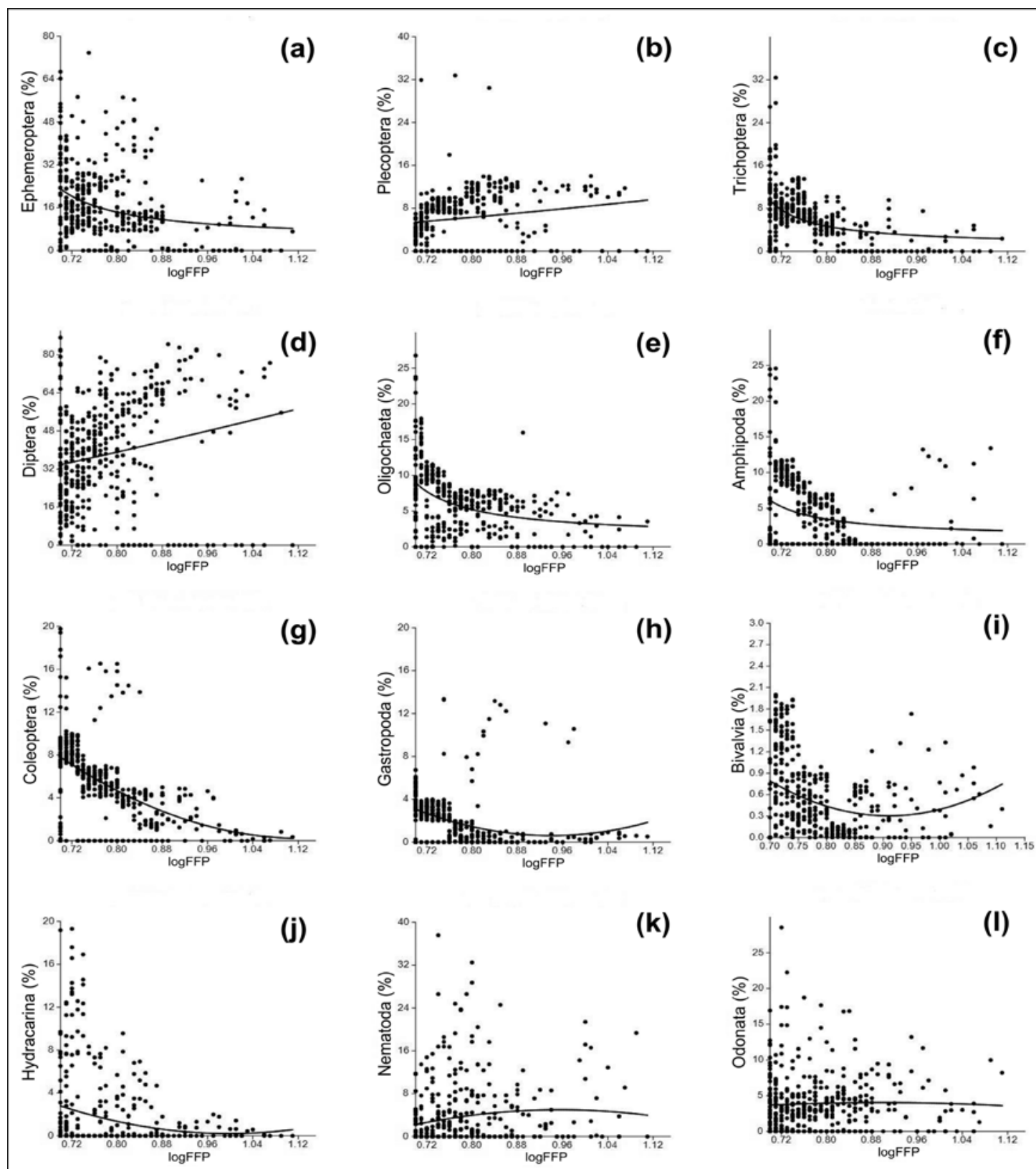

Figure 2: Scatterplots of the frequency versus flash flood potential (FFP) and plots of the 90th percentile quantile regression functions for (a) Ephemeroptera (b) Plecoptera (c) Trichoptera (d) Diptera, (e) Oligochaeta, (f) Amphipoda, (g) Coleoptera, (h) Gastropoda, (i) Bivalvia, (j) Hydracarina, (k) Nematoda, and (l) Odonata. 
The invertebrate fauna was classified into very coarse taxonomic groups (usually order) to support the testing hypotheses. Groups with a mean frequency across all sites below $5 \%$ were excluded from analysis (e.g. aquatic isopods, flatworms, and water bugs). For most invertebrate groups, the quantile regression models showed that FFP is an important factor influencing their frequency in samples (Tab. 1). The coefficients for the 90th percentile regression functions can also be found in table 1 . The main groups of tested macroinvertebrates responded differently to FFP variation (Fig. 2). Whilst the general trend of most groups was a decrease of their frequencies in samples directly with FFP values, there were a few exceptions, which either showed no direct response (e.g. Diptera and Odonata larvae; Tab. 1, Figs. 2d and 2l) or a slight increase of their frequency with FFP (e.g. stoneflies; Fig. 2b).

The explanatory variable in the $\mathrm{C}$ and RT analysis was the FFP. The full result of this analysis is summarised in table 2 as a list that yields the highest probability to obtain an optimum frequency for different groups of macroinvertebrates, using kick sampling method, for different classes of FFP. The variation of FFP was divided in classes as a direct consequence of node splits in regression trees by the CHAID technique (Tab. 2). According to results from table 2 and the general trend of nonlinear regressions (Fig. 2), the mayflies and caddisflies larvae, water beetles, oligochaetes, aquatic snails, mussels, and water mites decreased their frequency in samples with increasing FFP values. However, the general decline of various groups directly with FFP values, although nonlinear, encountered a slight increase at mid-level classes of FFP for stoneflies, amphipods and nematodes (Tab. 2). The FFP classes where these groups registered an increase of their frequencies varied widely, from within a narrow range of (4.8-5.6) for stoneflies, up to (3.6-5.6) for amphipods and (1.9-5.1) for nematodes (Tab. 2). Other groups, like Diptera and Odonata larvae, were apparently unaffected by FFP variation (Tab. 2, Fig. 2). The tendency for the former group was a slight increase in frequency with FFP values, whereas the latter provided an inconsistent variation with floods risk (Tab. 2).

\section{DISCUSSION}

The application of C and RT's analysis allowed us to estimate the optimum values for occurrence of different groups of invertebrates to different classes of FFP. Previously, this analysis was successfully employed to assess the water quality of aquatic habitats pollution with metals, eutrophication and impact of land use by using invertebrates as bioindicators (Moldovan et al., 2013; Pacioglu et al., 2016). However, in our study, the response of river invertebrates to FFP variation was not that acute as when they are faced with stressors like metal pollution, fluctuations in water $\mathrm{pH}$, eutrophication and colmation (Jones et al., 2012; Pacioglu et al., 2012; Moldovan et al., 2013). 
Table 1: Coefficients of the quantile regression models for the 90th percentile (equations in linearized form) for invertebrate groups, along with significance level of Wald test.

\begin{tabular}{|l|c|c|c|c|c|}
\hline Group & Intercept & St. error & FFP & St. error FFP & P value Wald test \\
\hline Ephemeroptera & 39.12 & 0.02 & -3.35 & 0.015 & $<0.001$ \\
\hline Plecoptera & 9.03 & 0.19 & 1.74 & 0.1 & 0.03 \\
\hline Trichoptera & 12.49 & 0.013 & -1.72 & 0.073 & $<0.001$ \\
\hline Diptera & 57.28 & 1.28 & 6.16 & 0.69 & 0.79 \\
\hline Oligochaeta & 12.86 & 0.05 & -1.77 & 0.03 & 0.04 \\
\hline Amphipoda & 11.18 & 0.19 & -1.29 & 0.1 & 0.007 \\
\hline Coleoptera & 9.8 & 0.11 & -1.44 & 0.06 & 0.005 \\
\hline Gastropoda & 4.23 & 0.11 & -0.5 & 0.06 & 0.008 \\
\hline Bivalvia & 1.16 & 0.002 & -0.14 & 0.001 & 0.003 \\
\hline Hydracarina & 8.38 & 0.06 & -1.27 & 0.033 & 0.025 \\
\hline Nematoda & 10.44 & 0.13 & 1.22 & 0.07 & 0.006 \\
\hline Odonata & 8.77 & 0.02 & -0.07 & 0.012 & 0.86 \\
\hline
\end{tabular}

Table 2: Optimum values of macroinvertebrate frequencies occurrence for different classes of FFP; the FFP classes were established as a direct consequence of node splits in regression trees by the CHAID technique.

\begin{tabular}{|l|c|c|c|c|c|c|}
\hline Group & $(0-1.96)$ & $(1.96-3.63)$ & $(3.63-4.8)$ & $(4.8-5.1)$ & $(5.1-5.6)$ & $(5.6-8)$ \\
\hline Ephemeroptera & 18.5 & 5.43 & 5.43 & 5.43 & 5.43 & 1.27 \\
\hline Plecoptera & 6.05 & 6.05 & 6.05 & 11.99 & 11.99 & 6.91 \\
\hline Trichoptera & 7.07 & 1.35 & 0.74 & 0.48 & 0.48 & 1.6 \\
\hline Diptera & 35.74 & 48.34 & 48.34 & 48.34 & 48.34 & 48.34 \\
\hline Oligochaeta & 6.88 & 4.42 & 3.45 & 2.27 & 2.27 & 1.58 \\
\hline Amphipoda & 4.86 & 2.56 & 5.87 & 5.44 & 5.44 & 3.37 \\
\hline Coleoptera & 6.24 & 2.56 & 2.07 & 0.26 & 0.82 & 0.26 \\
\hline Gastropoda & 2.22 & 0.91 & 0.91 & 0.91 & 0.6 & 0.6 \\
\hline Bivalvia & 0.59 & 0.41 & 0.41 & 0.41 & 0.41 & 0.41 \\
\hline Hydracarina & 2.03 & 0.66 & 0.63 & 0.62 & 0.64 & 0.64 \\
\hline Nematoda & 3.3 & 17.18 & 17.18 & 17.18 & 17.18 & 17.18 \\
\hline Odonata & - & - & - & - & - & - \\
\hline
\end{tabular}

Groups like mayflies, caddisflies, aquatic snails, mussels, oligochaetes, water mites, and water beetles decreased their frequency directly with the FFP. Although these groups (as many others) are capable of re-establishing viable population through aerial colonisation (e.g. insects and their associated water mite species), upstream migration or from the underneath hyporheic zone (Wallace, 1990; Dole-Olivier, 2011), it seems that the availability of coarse sediments usually associated with high FFP values (Pârvulescu et al., 2016) is not enough to overcome the steepness of slopes and the associated risks for washout during rainy seasons. The implementation of this index within the Romanian territory showed a high correlation not only with the steepness of slopes, but equally with water velocity (Pârvulescu et al., 2016). Although certain groups of mayflies (e.g. the heptageniids) and caddisflies 
(e.g. some rhyacophilids and hydropsychids) are generally associated with well oxygenated, high water flows (Armitage, 1995; Pîrvu and Pacioglu, 2012), their frequency, because of their large size, makes them less frequent in rivers with steep slopes as opposed to other groups of invertebrates. The molluscs are not great swimmers, nor equipped with special morphological adaptations like certain insect larvae to withstand the pressure induced by high flows (Kappes and Hasse, 2012). The sensitive nature of mussels makes them vulnerable to natural disasters, but their recovery is assured by the parasitic nature of their larvae on highly mobile fish (Vaughn, 2012).

Water beetles dwelling in rivers are usually associated with low-flow environments (Extence et al., 1999), characterised by small FFP values. The only notable exception (rifflebeetles), associated with high-flows and steep slopes (Extence et al., 1999), are still very vulnerable to spates (Elliott, 2008) and this could be another reason for their low frequency at high FFP values. The oligochaetes are known to have an affinity for fine sediments, either in benthic or hyporheic zone (Jones et al., 2012), therefore the use of interstitial milieu as refuge during floods (Dole-Olivier, 2011) may not be the most straightforward explanation for the observed pattern, but rather their preference for fine organic matter trapped in fine deposited sediments (Pacioglu et al., 2012) and hence their preference for lower FFP values. The water mites comprise a wide range of species, some of which are well adapted to high water speed and can prove very good swimmers (Di Sabatino et al., 2010). However, their preference for low FFP values may be a caveat associated with the sampling design. Because of their small size, the water mites usually belong to meiofauna (63-500 $\mu \mathrm{m}$ length; Rundle, 1990); therefore the probability of being trapped with the usual mesh size of hand nets used in this survey (one $\mathrm{mm}$ ) was greatly reduced, underestimating their real abundance in river habitats.

Three other groups, the amphipods, nematodes and stoneflies registered their highest percentage in samples at intermediary levels of FFP. Although the macroinvertebrate communities are considered to be highly sensitive to environmental changes (Pârvulescu and Hamchevici, 2010; Milner et al., 2013), it has been equally shown that high species abundance was associated with moderate/intermediate disturbances (Reice et al., 1990). Connell (1978) suggested that at an intermediate level of disturbance there will be sufficient time for colonisation by a wide variety of species, and that some of them can obtain the highest densities in such environmental conditions. The amphipods (due their high borrowing capacity), nematodes, and stoneflies (due their slender body shape) usually dwell in the hyporheic zone (Danielopol, 1989). Therefore, one possible explanation for their distribution is that at moderate levels of FFP, the interstitial habitats may prove a suitable refuge against high flows, as opposed to the aforementioned groups of invertebrates.

Other groups of organisms (Diptera and Odonata larvae) must be used cautiously in the attempt to describe the influence of FFP on their distribution, because they represent either extremely abundant taxa (Diptera) or their samples are infrequent (Odonata). The Diptera larvae (dominated by chironomids) are extremely abundant in streams and rivers worldwide and therefore their use as indicators of potential for wash out is unsuitable. The Odonata comprise families with a wide variety of flow and type of sediment preferences (Extence et al., 1999) and their usual big size compared to other invertebrates could be another reason for their rarity and consistent low percentage in samples, precluding any inference over the effect of FFP. The same lack of response was noticed for other important groups, like aquatic isopods, flatworms, and leeches, which because of low frequencies in samples $(<5 \%)$ prevented any meaningful response to FFP variation, according to both $\mathrm{C}$ and RT analyses and nonlinear regressions (data not shown). 
The coarse taxonomic level undertaken in this study consists with the patterns observed in other studies, which discovered that data aggregated to phylum-level were at least as well correlated with environmental stressors as those based on species identifications (Bowman and Bailey, 1997). Another important cost factor related to the level of taxonomic resolution needed in lotic invertebrate surveys resides in the low number of trained specialists in aquatic invertebrate taxonomy available in laboratories (Bonada et al., 2006). So far, different levels of taxonomy have been used in lotic invertebrate bio-monitoring (family, genus, and species), a fact that has been widely discussed in the context of costs and achieved accuracy and precision of the information associated with these taxonomic levels (Lenat and Resh, 2001; Schmidt-Kloiber and Nijboer, 2004). Therefore, in this context, the FFP can prove a useful method for environmentalists less trained in the cumbersome taxonomy of different groups of freshwater invertebrates, requiring only general skills for differentiating general groups of invertebrates in samples taken with a hand net. Another important benefit of this method is that it does not need costly travel costs generally related to routine monitoring programs (the FFP can be calculated solely based on the GPS coordinates of the site) and it is applicable to any scale, a major detail in current ecologic researches with a principal focus on general patterns occurring at large geographic gradients.

\section{CONCLUSIONS}

We conclude that the $\mathrm{C}$ and RT method can be used to assess the response of invertebrates from rivers to FFP. It is relatively easy to use (De'ath and Fabricius, 2007; Moldovan et al., 2013) and can therefore indicate optimum frequencies of specific groups of organisms that are sensitive to a given class of FFP and that can mirror the synergic combination of stressors, like potential for dislodging and indirectly of sediment structure and potential for refuge against high flows. This study was conducted on 408 sites, therefore covering a wide range of FFP values within the Romanian national territory.

Preliminary test of this variable can therefore prove to be a reliable basis for further research in describing the potential that it has in combinations with other stressors affecting freshwater life in streams and rivers.

\section{ACKNOWLEDGEMENTS}

This research was backed by a grant of the Romanian National Authority for Scientific Research and Innovation, UEFISCDI, project number PN-II-RU-TE-2014-4-0785. We thank the volunteer students involved during the work. 


\section{REFERENCES}

1. Anastasiu P., Preda C., Bănăduc D. and Cogălniceanu D., 2017 - Alien species of European Union concern in Romania, Transylvanian Review of Systematical and Ecological Research, 19.3, The Wetlands Diversity, ISSN-L 1841-7051, ISSN 2344-3219, 93-106.

2. Armitage P. D., 1995 - Faunal community change in response to flow manipulation, in The ecological basis for river management, Harper D. M. and Ferguson A. J. D. (eds), Wiley, Chichester, UK, 59-78.

3. Bailey R. C., Kennedy M. G., Dervish M. Z. and Taylor R. M., 1998 - Biological assessment of freshwater ecosystems using a reference approach: comparing predicted and actual benthic invertebrate communities in Yukon streams, Freshwater Biology, 39, 765-774.

4. Bonada N., Prat N., Resh V. H. and Statzner B., 2006 - Developments in aquatic insect biomonitoring: a comparative analysis of recent approaches, Annual Review of Entomology, 51, 495-523.

5. Bowman M. F. and Bailey R. C., 1997 - Does taxonomic resolution affect the multivariate description of the structure of freshwater benthic macroinvertebrate communities? Canadian Journal of Fisheries and Aquatic Sciences, 54, 1802-1807.

6. Connell J. H., 1978 - Diversity in tropical rain forests and coral reefs, Science, 199, 1302-1310.

7. Culp J. M. and Davies R. W., 1983 - An assessment of the effect of stream bank clear cutting on macroinvertebrate communities in a managed watershed, Canadian Technical Report of Fisheries and Aquatic Sciences, 1208.

8. Danielopol D. L., 1989 - Groundwater fauna associated with riverine aquifers, Journal of Northern American Benthological Society, 8, 18-35.

9. De'ath G. 2002 - Multivariate regression trees: a new technique for constrained classification analysis, Ecology, 83, 1103-1117.

10. De'ath G. and Fabricius K. E., 2007 - Classification and regression trees: a powerful yet simple technique for the analysis of complex ecological data, Ecology, 81, 3178-3192.

11. Di Sabatino A., Gereke R., Gledhill T. and Smith H., 2010 - Acari: Hydrachnidia II, in Gerecke R. (ed.), Chelicerata, Acari, II, Süsswasserfauna von Mitteleuropa, 7, 2-2, Elsevier Spektrum Akademischer Verlag, Heidelberg, 1-234.

12. Dole-Olivier M. J. 2011 - The hyporheic refuge hypothesis reconsidered: a review of hydrological aspects, Marine and Freshwater Research, 62, 1281-1302.

13. Dudgeon D. 1994 - The functional significance of selection of particles by aquatic animals during building behaviour, in The biology of particles in aquatic systems, 2nd edition, Wotton R. S. (ed.), Lewis Publishers, London, UK, 289-312.

14. Elliott J. M., 2008 - The ecology of riffle beetles (Coleoptera: Elmidae), Freshwater Reviews, 1, 189-203.

15. Eriksen C. H., 1966 - Ecological significance of respiration and substrate for burrowing Ephemeroptera, Canadian Journal of Zoology, 46, 93-103.

16. Extence C. A., Balbi D. M. and Chadd R. P., 1999 - River flow indexing using British benthic macroinvertebrates: a framework for setting hydroecological objectives, Regulated Rivers: Research and Management, 15, 543-574.

17. Jones J. I., Murphy J. F., Collins A., Sear D. A., Naden P. S. and Armitage P. D., 2012 - The impact of fine sediments on macroinvertebrates, River Research and Applications, 28, 10551071.

18. Kappes H. and Haase P., 2012 - Slow, but steady: dispersal of freshwater molluscs, Aquatic Sciences, 74.1, 1-14.

19. Kass G. V. 1980 - An exploratory technique for investigating large quantities of categorical data, Journal of Applied Statistics, 29, 119-127.

20. Kley A., Kinzler W., Schank Y., Mayer G., Waloszek D. and Maier G., 2009 - Influence of substrate preference and complexity on co-existence of two non-native gammarideans (Crustacea: Amphipoda), Aquatic Ecology, 43, 1047-1059. 
21. Lake P. S., Palmer M. A., Biro P., Cole J., Covich A. P., Dahm C., Gibert J., Goedkoop W., Martens K. and Verhoeven J., 2000 - Global change and the biodiversity of freshwater ecosystems: impacts on linkages between above-sediment and sediment biota: all forms of anthropogenic disturbance changes in land use, biogeochemical processes, or biotic addition or loss not only damage the biota of freshwater sediments but also disrupt the linkages between above-sediment and sediment-dwelling biota, BioScience, 50, 12, 1099-1107.

22. Lancaster J. and Belyea L. R., 2006 - Defining the limits to local density: alternative views of abundance-environment relationships, Freshwater Biology, 51, 783-796.

23. Lemly A. D. 1982 - Modification of benthic insect communities in polluted streams: combined effects of sedimentation and nutrient enrichment, Hydrobiologia, 87, 229-245.

24. Lenat D. R. and Resh V. H., 2001 - Taxonomy and stream ecology - the benefits of genus- and species-level identifications, Journal of the North American Benthological Society, 20, 287-298.

25. Marić S., Stanković D., Wazenbök J., Šanda R., Erös T., Takács A., Specziár A., Sekulić A., Sekulić N., Bănăduc D., Ćaleta M., Trombitsky I., Galambos L., Sipos S. and Snoj A., 2017 Phylogeography and population genetics of the European mudminnow (Umbra krameri) with a time-calibrated phylogeny for the family Umbridae, Hydrobiologia, 792, 1, 151-168, DOI 10.1007/s10750-016-3051-9, ISSN 0018-8158, Eissn 1573-5117.

26. Merritt R. W. and Cummins K. W. (eds) 1996 - An introduction to the aquatic insects of North America, insects of North America 3rd edition, Kendall/Hunt Publishing Co., Dubuque. Iowa, USA, 862.

27. Milner A. M., Robertson A. L., McDermott M. J., Klaar M. J. and Brown L. E., 2013 - Major flood disturbance alters river ecosystem evolution, Nature Climate Change, 3, 137-141.

28. Moldovan O. T., Melegi I., Levei E. and Terente M., 2013 - A simple method for assessing biotic indicators and predicting biodiversity in the hyporheic zone of a river polluted with metals, Ecological Indicators, 24, 412-420.

29. Nebeker A. V., 1972 - The effect of low oxygen concentration on survival and emergence of aquatic insects, Transactions of the American Fisheries Society, 101, 675-679.

30. Pacioglu O., Shaw P. and Robertson A., 2012 - Patch scale response of hyporheic invertebrates to fine sediment removal in two chalk rivers, Archiv für Hydrobiologie, 4, 283-288.

31. Pacioglu O., Moldovan O. T., Shaw P. and Robertson A., 2016 - Response of invertebrates from the hyporheic zone of chalk rivers to eutrophication and land use, Environmental Science and Pollution Research, 23, 4729-4740.

32. Palmer M. A., Arensburger P., Martin A. P. and Denman D. W., 1996 - Disturbance and patchspecific responses: the interactive effects of woody debris and floods on lotic invertebrates, Oecologia, 105, 247-257.

33. Pârvulescu L. and Hamchevici C., 2010 - The relation between water quality and the distribution of Gammarus balcanicus Schaferna 1922 (Amphipoda: Gammaridae) in the Anina Mountains, Carpathian Journal of Earth and Environmental Sciences, 5, 161-168.

34. Pârvulescu L., Zaharia C., Groza M., Csillik O., Satmari A. and Drăguţ L., 2016 - Flash-flood potential: a proxy for crayfish habitat stability, Ecohydrology, 9, 1507-1516.

35. Pennak R. W. 1989 - Fresh-water invertebrates of the United States: Protozoa to Mollusca, John Wiley and Sons, New York, USA, 268.

36. Pîrvu M. and Pacioglu O., 2012 - The ecological requirements of caddisflies larvae (Insecta: Trichoptera) and their usefulness in water quality assessment of a river in south-west Romania, Knowledge and Management of Aquatic Ecosystems, 407, 03.

37. Reice S. R., Wissmar R. C. and Naiman R. J., 1990 - Disturbance regimes, resilience, and recovery of animal communities and habitats in lotic ecosystems, Environmental Management, 14, 647-659.

38. Relyea C., Minshall D., Wayne G. and Danehy R. J., 2012 - Development and validation of an aquatic fine sediment biotic index, Environmental Management, 49, 242-252. 
39. Resh V. H., Brown A. V., Covich A. P., Gurtz M. E., Li H. W., Minshall W. G., Reice S. R., Sheldon A L., Wallace J. B. and Wissmar R. C., 1988 - The role of disturbance in stream ecology, Freshwater Science, 7, 4, 433-455.

40. Rundle S. D. 1990 - Micro-arthropod seasonality in streams of varying pH, Freshwater Biology, 24, 411-431.

41. Schmidt-Kloiber A. and Nijboer R. C., 2004 - The effects of taxonomic resolution on the assessment of ecological water quality classes, Hydrobiologia, 516, 269-283.

42. Staicu G., Bănăduc D. and Găldean N., 1998 - The structure of some benthic macroinvertebrates and fishes communities in the Vişeu Watershed, Maramureş, Romania, Travaux du Museum National d Histoire naturelle Grigore Antipa, Bucureşti, 587-608, XL.

43. Statzner B. and Beche L. A., 2010 - Can biological invertebrate traits resolve effects of multiple stressors on running water ecosystems? Freshwater Biology, 55, 80-119.

44. Storey A. W., Edward D. H. D. and Gazei P., 1991 - Surber and kick sampling: a comparison for the assessment of macroinvertebrate community structure in streams of south-western Australia, Hydrobiologia, 211, 111-121.

45. Tronstad L. M., Tronstad R. P. and Benke A. C., 2007 - Aerial colonization and growth: rapid invertebrate responses to temporary aquatic habitats in a river floodplain, Journal of the North American Benthological Society, 26, 460-471.

46. Townsend C. R. and Hildrew A. G., 1994 - Species traits in relation to a habitat templet for river systems, Freshwater Biology, 31, 265-275.

47. Vaughn C. C., 2012 - Life history traits and abundance can predict local colonisation and extinction rates of freshwater mussels, Freshwater Biology, 57, 982-992.

48. Wallace J. B. 1990 - Recovery of lotic macroinvertebrate communities from disturbance, Environmental Management, 14, 605-620.

49. Warwick R. M. 1988 - The level of taxonomic discrimination required to detect pollution effects on marine benthic communities, Marine Ecology Progress Series, 19, 259-268.

50. Weigel B. M., Wang L., Rasmussen P. W., Butcher J. T., Stewart P. M., Simon P. and Wiley M. J., 2003 - Relative influence of variables at multiple spatial scales on stream macroinvertebrates in the Northern Lakes and Forest ecoregion, USA, Freshwater Biology, 48, 1440-1461.

51. Wiley M. J. and Kohler S. L., 1980 - Position changes of mayfly nymphs due to behavioural regulation of oxygen consumption, Canadian Journal of Zoology, 58, 618-622.

52. Williams D. D., Taveres A. F. and Bryant E., 1987 - Respiratory device or camouflage? A case for the caddisfly, Oikos, 50, 42-52. 